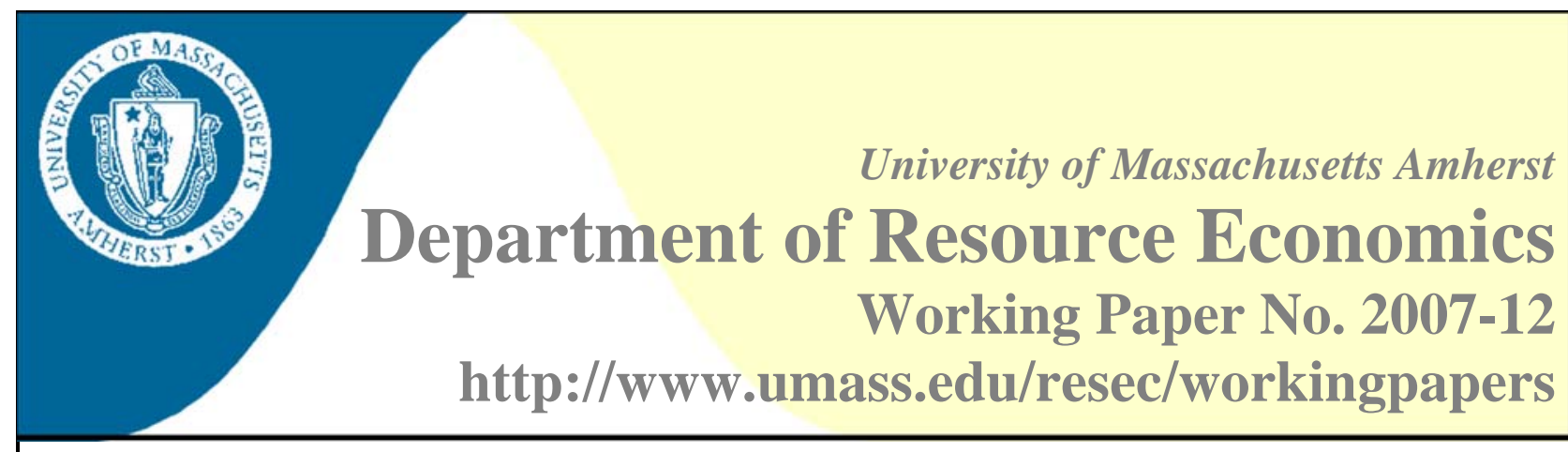

\title{
Labor Supply Decisions of Rural Low-Income Mothers
}

\author{
Sheila Mammen ${ }^{1}$, Daniel Lass ${ }^{2}$, and Sharon B. Seiling ${ }^{3}$
}

\begin{abstract}
:
Labor force participation is crucial to the economic well-being of low-income rural families. This study identified the factors that influence two decisions that low-income rural mothers make regarding their employment: labor force entry and number of hours supplied to employment. The sample consisted of 412 rural low-income mothers who participated in a multi-state study. The logistic regression model correctly predicted 80 percent of their work participation decisions. Employed rural mothers appeared to be older, better educated, and less likely to suffer from depression compared to those not working. Additionally, they were more likely to have an employed partner, a driver's license, child care assistance, and Earned Income Tax Credit from the previous year. The estimated labor supply function explained 33 percent of the variation in hours worked by the 208 employed rural mothers. Higher wages, availability of health insurance, and overtime benefits predicted the number of hours that these employed mothers were willing to work.
\end{abstract}

Keywords: Rural Low-income Mothers, Labor Force Participation, Women’s Labor Supply, Welfare Reform

JEL Classification: D13, I38, J24, R29

\footnotetext{
${ }^{1}$ Sheila Mammen, Department of Resource Economics University of Massachusetts, 303 Stockbridge Hall

80 Campus Center Way, Amherst, MA 01003-9246

E:smammen@resecon.umass.edu P: 413-545-2470 F: 413-545-5853

${ }^{2}$ Daniel Lass, Department of Resource Economics University of Massachusetts, 211 Stockbridge Hall 80 Campus Center Way, Amherst, MA 01003-9246

E: dan.lass@resecon.umass.edu P: 413-545-1501 F: 413-545-5853

${ }^{3}$ Sharon B. Seiling, Department of Consumer Studies

Ohio State University, 265 Campbell Hall

Columbus, OH 43210

E: sseiling@ehe.ohio-state.edu
} 


\title{
Labor Force Supply Decisions of Rural Low-Income Mothers
}

\author{
Sheila Mammen, Ph.D. \\ Associate Professor \\ Department of Resource Economics \\ University of Massachusetts Amherst \\ 303 Stockbridge Hall \\ Amherst, MA 01003 \\ (413) 545-2470 \\ smammen@resecon.umass.edu \\ Daniel Lass, Ph.D. \\ Professor \\ Department of Resource Economics \\ University of Massachusetts Amherst \\ 211 Stockbridge Hall \\ Amherst, MA 01003 \\ (413) 545-1501 \\ dan.lass@resecon.umass.edu \\ Sharon B. Seiling, Ph.D. \\ Associate Professor \\ Department of Consumer Sciences \\ Ohio State University \\ 265 Campbell Hall \\ Columbus, OH 43210 \\ (614) 292-4224 \\ sseiling@ehe.ohio-state.edu
}




\title{
Labor Force Supply Decisions of Rural Low-Income Mothers
}

\begin{abstract}
Labor force participation is crucial to the economic well-being of low-income rural families. This study identified the factors that influence two decisions that low-income rural mothers make regarding their employment: labor force entry and number of hours supplied to employment. The sample consisted of 412 rural low-income mothers who participated in a multistate study. The logistic regression model correctly predicted 80 percent of their work participation decisions. Employed rural mothers appeared to be older, better educated, and less likely to suffer from depression compared to those not working. Additionally, they were more likely to have an employed partner, a driver's license, child care assistance, and Earned Income Tax Credit from the previous year. The estimated labor supply function explained 33 percent of the variation in hours worked by the 208 employed rural mothers. Higher wages, availability of health insurance, and overtime benefits predicted the number of hours that these employed mothers were willing to work.
\end{abstract}

Keywords: Rural Low-income Mothers, Labor Force Participation, Women’s Labor Supply, Welfare Reform 


\section{Introduction}

Paid employment can lift families out of poverty if it enables them to achieve economic self-sufficiency. Employment is especially beneficial to low-income women who are far more likely than men to become single custodial parents. As these low-income mothers become economically secure through employment, they are less likely to require welfare assistance. This is particularly true for families in rural areas where poverty is disproportionately higher and more persistent (Weber \& Jensen, 2004). Employment may also lead to a better quality of life. With higher incomes and greater purchasing power, rural working families may have greater access to better housing, dependable child care, and reliable transportation, assuming that these are available in the community. Paid employment is also considered to be central to the mental health of individuals (Warr, 1999); it can contribute to an individual's self esteem which, in turn, may help reduce stress. In addition, results of prior studies have shown that among low-income families, voluntary maternal employment can have positive outcomes for children (Zaslow \& Emig, 1997). Children who live in households with stable family income and parents who are able to maintain their employment are better off in the long run (Boushey, 2002). Finally, a working mother might serve as a positive role model for children, especially daughters, encouraging them to participate in the labor force as adults.

In spite of the many benefits of employment, not all low-income mothers are able or willing to engage in market work because, for many, the costs of employment exceed its economic benefits. Although, in general, low-income mothers may have a choice of participating in the labor force, this is no longer the case for those mothers who are welfare-reliant. The 1996 welfare reform legislation requires TANF (Temporary Assistance to Needy Families) recipients 
to transition into employment. This is based on the expectation that those who are able to exit the welfare system and remain employed are more likely to attain a safe and decent standard of living for themselves and their families (Boushey, 2002). Welfare recipients are also restricted to a lifetime limit of five years and no more than two consecutive years when they can receive benefits. However, even with the imposed work requirements and time limits, not all welfarereliant mothers enter the labor force.

From a policy perspective, low-income mothers' participation in the labor market is a highly desired goal. This paper examines the effect of various factors that may contribute to the work participation decisions of rural low-income mothers, including those who receive welfare. Some of these factors come directly from the mother such as her individual and job characteristics, and her human capital. Other factors considered in the employment decision model include household characteristics, household income sources, and county unemployment rates. In addition, we investigate factors that determine the number of hours low-income rural mothers will supply to the labor force, once they decide to work. Policy implications for the economic well-being of rural families and rural communities, based on the results of this study, will be discussed.

\section{Background and Literature Review}

Traditionally, women have been less likely than men to seek full-time paid employment and their labor force participation rates usually declined with family responsibilities. Since the end of World War II, however, women's labor market attachment has grown and they have assumed an increasingly significant role in the labor force (Shank, 1988). Today, with almost $60 \%$ of them employed, women make up about $46 \%$ of the labor force (U.S. Department of Labor, 2007). 


\section{Employment Trends and Poverty Rates}

In the past decade increasing numbers of low-income parents, mothers in particular, have entered the labor market (Ross Phillips, 2002). In the case of welfare-reliant families, overwhelmingly headed by women, a significant number left the welfare system and were employed in the mid- and late 1990s (Sherman, Fremstad \& Parrott, 2004). Indeed, since 1994, the employment rates among single mothers, the group most affected by welfare reform, rose from 60 percent in 1994 to 72 percent in 1999. Still more dramatically, during this same time, the labor force participation rates among single mothers who were the most disadvantaged rose from 47 percent to 65 percent (Moffitt, 2002). This group, whose employment gains were the greatest, included those single mothers who were between the ages of 18 and 29, had children under the age of seven, were high school dropouts, and were black or Hispanic (O’Neill \& Hill, 2001). Their increase in work effort was accompanied by a decline in TANF receipts and a decrease in poverty rates (Danziger, 2002); the poverty rate among female-headed households declined from $34.6 \%$ in 1994 to $25.4 \%$ in 2000 (U.S. Census Bureau, n.d.). Nevertheless, while their incomes have generally risen, they are only slightly above what they were when they were on welfare (Moffitt). The Project on Devolution and Urban Change, a study of the implementation and effects of welfare reform on women from Cleveland, Los Angeles, Miami, and Philadelphia, found that although the majority of the current and former welfare recipients achieved high employment stability, most were in jobs with low earnings; without other sources of income, they were unable to lift their families out of poverty (Polit, et al., 2001).

It should be noted that after reaching an employment rate high of 73.0 percent in 2000 , single mothers' labor force participation dropped to about 69.8 percent in 2003, a decline not observed, specifically, among other parents or in the population as a whole (Sherman et al., 
2004). Several studies (Colton, Bania, Martin \& Lalich, 2003; Fremstad, 2004; Loprest, 2003)

have found that families who left welfare after 2000 were less likely to work compared to those who left in the 1990s. Furthermore, the proportion of families referred to as "disconnected," i.e., those who were not working, did not have a working spouse, and were not receiving cash benefits, increased as well (Loprest).

The success of welfare reform hinges on the ability of the poor to attain and maintain gainful employment and see growth in real wages. Unfortunately, many single mothers and welfare recipients who most frequently found work in the late 1990s were in industries that were hit the hardest during the recent economic slowdown. This included jobs in service industries such as retail trade, hospitality, temporary help, and home health, as well as in manufacturing (Boushey \& Rosnick, 2004). Since many former welfare recipients tend to have shorter job tenure compared to other low-income mothers (Boushey, 2002), it is plausible that their shorter employment histories make them the last hired and the first fired (Boushey \& Rosnick). In general, welfare recipients are most likely to be employed in low-wage jobs that require less education (Bartik, 1997) and, unfortunately, many are unprepared to handle the demands of a job such as being punctual and getting along with supervisors and co-workers (Berg, Olson \& Conrad, 1992; Quint \& Musick, 1994).

\section{Employment in Rural Communities}

Urban and Olson (2005) found the unemployment rate of the local community to be a significant predictor of low-income mothers' employment. The employment decisions of rural low-income mothers are partly dependent on local labor market conditions, such as economic growth, employment rate, availability and types of jobs, and wage rates, that may be different from urban areas. The remoteness and small scale of many rural communities are traditionally 
considered factors that inhibit economic growth, however, a micro view of rural economic performance in the 1990s found that, compared to neighboring metropolitan areas, employment grew faster in several rural areas that were located near a metropolitan area and either contained a rural industry cluster or benefited from urban spillover (Henry \& Drabenstott, 1996).

Nevertheless, underemployment is considered a greater problem in rural areas and, although, many among the rural poor may find jobs, they are more likely to find marginal jobs (Feindis \& Jensen, 1998) that pay less, have few benefits and little opportunity for advancement.

The labor market conditions varied across the sites in a study of 12 rural areas in Alabama, Arkansas, California, and Maine; most of the jobs were either part-time or intermittent and were not dependent on agriculture (McKernan, Lerman, Pindus \& Valente, 2002). These jobs, especially among women, were mostly in the service industry that usually paid the minimum wage and provided few opportunities for advancement. Although it is usually assumed that low-income mothers, most of whom are welfare-reliant, have fewer job possibilities in rural communities, McKernan et al. found that the employment level of rural single mothers was similar to those in metropolitan areas prior to welfare reform. In addition, they reported that single mothers' employment rate gained almost as much in rural communities as it did in metropolitan areas after reform.

\section{Factors Affecting the Employment of Low-Income Mothers}

According to Schultz (1961), individuals' productive potential in the labor market is affected by their stock of human capital. Low-income mothers, in general, face a variety of obstacles that either prevent them from labor force participation or are serious impediments to achieving their productive potential at work. Martinson (2000) examined the effect of several variables on those who had moderate, limited, or little success in remaining employed. Those 
who were most successful in sustaining employment had the highest levels of education and skill, a recent work history, and fewer personal barriers. Variables that were less likely to affect the success of their employment were their age, ethnicity, marital status, number and age of children, and depression levels.

Previous studies have shown that mothers' labor force participation is not related to negative achievements or behavioral outcomes of their school-aged or older children (Harvey, 1999; Perry-Jenkins, Repetti \& Crouter, 2000; Zaslow \& Emig, 1997). Family income is more important to the child's well-being than hours worked by the mothers. Job characteristics, such as flexible work schedules and family leave, have a greater effect on child well-being than levels of maternal employment (Ross Phillips, 2002). A more critical issue that confronts a mother in her decision to participate in the labor market is who will take care of her children. There are many dimensions to this question including type, cost, quality, and reliability of child care. The solution to the problem of child care will also affect the mother's number and choice of work hours (Connelly \& Kimmel, 2000).

Child care can take as much as $35 \%$ of the income of poor families (Committee on Ways and Means, 2000), and this affects employment, especially for single mothers (Ribar, 2000). Using data from the Survey of Income and Program Participation (SIPP), Connelly and Kimmel (2000) examined the effects of the costs and modes of child care on the employment status of married and single mothers. For all mothers, full-time employment was more elastic with respect to changes in the price of child care than was part-time employment. The employment elasticities were greater for single mothers than for married mothers. Among single mothers, working parttime was dependent on their wages and the price of child care, because paid part-time child care was often more expensive per hour than was full-time child care. In addition, full-time 
employment for both married and single mothers was more likely to be associated with an increase in the use of center-based child care and a decrease in reliance on relatives for child care. The price elasticities of modal choice were greater for single mothers than married mothers. Unlike single mothers, married mothers were more likely to seek part-time employment because they were able to rely on fathers and other relatives for child care (Connelly \& Kimmel).

Social support, both formal and informal, has been linked to family well-being (Edin \& Lein, 1997). This held true for wage-reliant as well as welfare-reliant families. Working mothers were found to have stronger networks to draw on than unemployed mothers (Edin \& Lein) and families in which one member had a job that paid a living wage and provided benefits were better able to gain from the informal exchanges than those with no member in paid employment or with jobs with low pay (Nelson \& Smith, 1999). Support networks of rural families, women, and low-income families are typically dominated by kin (Beggs, Haines \& Hurlbert, 1996), and kin networks provide most of the support for their members (Hao, 1996; Lin \& Dumin, 1986; Miller \& Darlington, 2002; Wellman \& Wortley, 1990). Their support often comes in the form of practical services such as child care and transportation, which enable low-income mothers to work in paid jobs. Working mothers who believe that maternal care is best for their children and who believe that their employment is detrimental for their children, frequently choose their own mothers as care givers (NICHD Early Child Care Research Network, 1997; Wheelock, Oughten \& Baines 2003). Rural mothers and those in jobs that have variable schedules or part-time arrangements also use their mothers for child care (Brewster \& Padovic 2002; Hunts \& Avery 1998). Overall, support from kin is believed to provide a sense of satisfaction that other network support does not (Wan, Jaccard \& Ramey, 1996). 
A high percent of welfare-reliant mothers are victims of domestic violence (Bassuk et al., 1996; Curcio, 1997; Lloyd, 1996) and these women are less likely to join the labor force (Colton, Cosenza \& Allard, 1996). Many previous studies have reported that poor mental and physical health among mothers and children can be a significant barrier to maternal employment (Acs \& Loprest, 1999; Brandon \& Hogan, 2001; Lee, Oh, Hartmann \& Gault, 2004). Welfare recipients appear to experience a higher incidence of mental health problems than non-recipients (Leon \& Weissman, 1993; Moore et al., 1995; Quint, Polit, Bos \& Cave, 1994). Symptoms of maternal depression along with low literacy were documented as obstacles that most frequently hindered employment (Olson \& Pavetti, 1996; Zaslow, Hair, Dion, Ahluwalia \& Sargent, 2001).

Low-income mothers who were the most successful in maintaining employment were more likely to work in full-time jobs if they had publicly- or privately-funded health insurance and other employer benefits such as paid sick and vacation leave (Martinson, 2000). Employerprovided health insurance is a critical consideration in the choice of a job for former welfare recipients; those who receive this benefit are 2.6 times more likely to remain employed after three years compared to those who do not (Boushey, 2002). It is the high-quality jobs that offer better wages, paid vacation, sick time and, more importantly, affordable health insurance. Women with disabilities are less likely to have the appropriate education and advanced skills to qualify for these higher-quality jobs that provide desired benefits, many of which are essential, if mothers or their children have disabilities (Lee et al., 2004).

Government policies can serve as either barriers or incentives to employment. In a study of unwed mothers, the year after childbirth, Livermore and Powers (2006) found that the mothers were less likely to be employed if they received assistance from government programs such as TANF, food stamps, housing subsidies, SSI, and public housing. On the other hand, the Earned 
Income Tax Credit (EITC) has had the greatest effect on the labor force participation of unmarried mothers (Meyer \& Rosenbaum, 2001) and is considered the single most important policy for increasing work among these mothers (Ellwood, 2000; Grogger, 2003; Hotz \& Scholz, 2003). Looney (2005) found that the EITC, financial incentives, and growth in employment and wages account for half of the decline in welfare use and a quarter of employment growth between 1993 and 1999. While policies like sanctions and work requirements reduced welfare use, they did not, however, contribute proportionately to increases in employment.

Time limits, designed to force welfare recipients to transition out of assistance, would serve, for some, as an incentive to seek employment even before they reach their limit. They may keep working and stay off welfare in order to preserve their remaining time for possible future needs. Others may wait until their assistance runs out before they start looking for work. Using data from the Consumer Population Surveys, Grogger (2003) concluded that time limits accelerated job search and increased employment; however, it had no significant effect on family income.

Earnings supplement programs, such as the Self Sufficiency Project and Minnesota Family Investment Program, have been found to encourage work. When these programs were combined with employment services, they were even more successful in increasing employment (Bloom \& Michalopoulos, 2001). The robust economy of the 1990s produced strong labor demand that boosted wages, especially at the low-end of the pay scale. This was essential in transitioning families from welfare to the labor force and increasing employment and incomes (Boushey, 2002). The converse, a situation where there is high unemployment or few jobs, will discourage low-income families from seeking work. 


\section{Rural Low-Income Mothers and Barriers to Employment}

According to McKernan et al. (2002), the barriers faced by rural low-income families do not result in employment levels that are any lower than those of urban families. Since rural areas are becoming more economically and culturally integrated (Duncan, Whitener \& Weber, 2002), both rural and urban families face a similar set of employment barriers. However, the lower population density in rural areas presents more challenges to low-income families; jobs, job training, employment services, child care, health care, and auxiliary social services are more difficult to access without reliable transportation and sufficient funds. McKernan et al. cited inadequate transportation and limited access to employment services as the two most serious barriers facing rural welfare-reliant mothers. It is, however, possible that the lack of formal support systems available to rural low-income families may, to some degree, be compensated for by the greater reliance on their extended family, thus, enabling mothers to enter the labor force (Duncan et al.).

Personal characteristics, such as lower levels of educational attainment, are significant barriers to employment in rural areas, particularly in the rural South. Unemployment rates are generally higher in rural areas because steady employment is harder to find; jobs tend to be part-

time and pay only minimum wage. Also, smaller employers, who are less likely to provide health insurance, are more prevalent in rural areas. This is worth noting because the access to Medicaid benefits is a major consideration in the employment decisions of rural mothers. Yet another important factor to rural mothers is child care subsidies, sometimes seen as being more relevant to employment than the availability of child care (McKernan et al., 2002).

Drawing on the literature and economic theory, the authors have developed the following two hypotheses: 
$\mathrm{H}_{1}$ : Rural low-income mothers who have higher levels of human capital, lower non-wage income, older children, greater access to childcare subsidies, and live in counties with lower unemployment rates are more likely to work in paid employment, and $\mathrm{H}_{2}$ : Employed rural low-income mothers who have higher levels of human capital, higher wages, older children, and job benefits will supply more hours to the labor force.

\section{Models}

Rural low-income mothers' labor supply decisions are explained using microeconomic analysis. This is a useful approach because neoclassical economics is a study of individual decision-making under conditions of scarcity; the assumptions made are that individuals recognize opportunity costs and behave rationally. According to Blau, Ferber, and Winkler (2002), economic theories and models "should not be judged primarily on its detailed resemblance to reality, but rather in terms of the extent to which it enables us to grasp the salient features of that reality." They conclude that by raising awareness of the present, economic theory can help, at best, to correctly predict the future.

Working families face many realities that a standard microeconomic model may not be able to take into account and explain. While this inability to explain all of the circumstances and nuances experienced by low-income families is a limitation of our model, nonetheless, it provides some clarity as to how rural low-income mothers decide to work or not to work and, additionally, how many hours they would supply the labor force.

\section{Modeling the Work Decision}

Each rural low-income mother has some chance of working, either by choice (accept a job, or do not accept a job), or because there is some chance that she will be hired for a given job. Let us assume that the work/do not work choice is one that is faced by the woman and that 
this decision is made based on some optimization problem she solves; we assume this choice is based on maximization of her utility, subject to budget and time constraints. She would then compare the marginal utility of leisure ${ }^{1}$ to the marginal utility of goods consumed with the income obtained from her job (see, for example, Blundell \& MaCurdy, 1999; Mroz, 1987). The comparison results in an unobservable index, the difference between the additional utility that can be gained from taking the wage offer and the marginal utility of leisure:

$$
I_{i}^{*}=\mu \cdot w_{i}-\frac{\partial U_{i}}{\partial L_{i}} \gtreqless 0
$$

where $I_{i}^{*}$ is the unobserved difference, $\mu \cdot w_{i}$ is the additional utility that can be gained from spending her market wage $w_{i}$ on goods and services, and $\partial U_{i} / \partial L_{i}$ is the marginal utility of leisure. Each individual makes this comparison at the time of the job offer and accepts the offer or declines it. While we do not observe $I_{i}^{*}$, we do observe a binary indicator of whether or not the wage offer was accepted:

$$
I_{i}=\left\{\begin{array}{l}
1 \text { if } \mu \cdot w_{i}-\frac{\partial U_{i}}{\partial L_{i}}=I_{i}^{*}>0 \\
0 \text { if } \mu \cdot w_{i}-\frac{\partial U_{i}}{\partial L_{i}}=I_{i}^{*} \leq 0
\end{array}\right.
$$

The binary decision then depends upon factors that would alter the unobservable index, $I_{i}^{*}$. If a rural mother receives a higher wage offer, her probability of working increases; the probability that we observe $I_{i}=1$ increases. We only observe wages if the mother has chosen to work. However, we assume that wage offers are determined by human capital variables. Factors that

\footnotetext{
${ }^{1}$ Economic theory has settled on referring to "non-market time" as "leisure."
} 
shift the individual's utility function will also affect the unobservable index, $I_{i}^{*}$. These independent variables include those factors identified in the review of literature presented above. Human capital may affect the ability of the rural mothers to find a job they can apply for and then secure. The human capital factors used here are education, maternal risk of depression, being licensed to drive, and life skills such as being able to create a resume, locate job training, secure child care, and apply for jobs. Individual characteristics including age and ethnicity may affect both the wage offer and the mother's utility function. This may also be true of household characteristics including household size, age of the youngest child, availability of child care assistance, whether living with a partner, partner's work status, and if the individual experienced domestic abuse. Important also are levels of other non-wage income including TANF payments and the EITC. Finally, we assume that local economic conditions will affect the probability of work. The county employment rate may be an important indicator of local economic activity and job availability.

\section{Modeling the Labor Supply Decision}

If the mother accepts the wage offer, we then assume she can also choose the hours worked. Labor supply decisions represent the number of hours that is optimal for an individual, the hours that would maximize utility, given that the decision to supply labor has been made $\left(I_{i}^{*}>0\right)$. Hours supplied then depend on wages, other income sources, and factors that affect the marginal utility of leisure. We anticipate that higher wages lead to more hours supplied. However, the effect of a wage increase on hours worked includes both substitution and income effects. At some point, additional wages may lead to a reduction of hours worked as a negative income effect dominates over the positive substitution effect. In addition, there may be 
disincentives to supply more hours at higher wages, as certain support may be lost with greater levels of wage income.

The wage included in the labor supply models may be endogenous or a random variable. If this were to be the case, then the estimated effect of wage on hours supplied would be biased and inconsistent. Employing an instrumental variables approach to estimation solves the econometric problem of a random regressor. Potential instruments should be highly correlated with the wage, but uncorrelated with the stochastic disturbance. Candidates include factors that might determine wages; theoretically, an individual's stock of human capital is argued to be a major determinant of wages.

\section{Data and Methods}

Data used for this research were part of the USDA-funded multi-state longitudinal project, NC-223/NC1011, "Rural Low-Income Families: Tracking Their Well-Being and Functioning in the Context of Welfare Reform" (see http://fsos.cehd.umn.edu/projects/rfs.html for a complete project description). Data collected from August 1999 to July 2000 were used. The sample consisted of 412 rural low-income families from 23 counties in 13 states. The states represented all regions of the country: California, Indiana, Kentucky, Louisiana, Massachusetts, Maryland, Michigan, Minnesota, Nebraska, New Hampshire, New York, Ohio, and Oregon. To be eligible for the study, families had to have annual incomes at or below 200 percent of the Federal poverty line and at least one child under the age of 13 years. Within each rural county, families were chosen to represent the diversity in the types of families with children who were considered low-income, with Hispanic mothers being over sampled. The mothers were recruited through programs that serve such families including the Food Stamp Program, Supplemental Program for Women, Infants, and Children (WIC), food pantries, survival centers, housing 
authority programs, and welfare-to-work programs. This purposive sampling limits the generalizability of the results. Nonetheless, because the families were recruited broadly from various agencies and represent states in all regions, the findings will provide additional insight on low-income rural mothers' decision to enter the labor force.

Trained interviewers collected in-depth qualitative and quantitative data from the mothers, during face-to-face interviews at a site of the respondents' choice. The semi-structured protocol included questions on a variety of domains including socio-demographics, employment, and objective as well as subjective measures of income. Where necessary, interviews were conducted in Spanish.

\section{Sample Description}

Half of the 412 rural mothers (50.4\%) who participated in the study were working; the rest $(49.6 \%)$ were not working at the time of the interview (see Table 1 ). The median age of those working (28 years) was slightly higher than those who were not (27 years). Regardless of their working status, two-thirds of them were White non-Hispanic, slightly more than $20 \%$ were Hispanic, and about 9\% were African American. About half of those working (53.4\%) were married or had a partner, the rest were single, divorced or separated. By comparison, over twothirds of unemployed mothers were married. Over three-fourths (77\%) of working mothers had at least a high school education, compared to only $60 \%$ of the non-working mothers. Regardless of the working status of the mothers, about half of their spouses or partners worked. A slightly larger proportion of the working mothers $(39 \%)$ had three or more children, compared to $36 \%$ of the non-working mothers. The working mothers had a higher median monthly income, $\$ 1,382$, compared to those who were not working, $\$ 1,189$. 


\section{Results}

\section{Probability of Work}

The probability of maternal employment was modeled using logistic regression (see Table 2). Logistic regression and probit offer comparable results; however, logistic regression results have a convenient interpretation - each parameter estimate can be transformed into an “odds-ratio.” In general, the logistic regression model performed well; 80.2 percent of the work decisions were correctly predicted by the model, while 19.6 percent were predicted incorrectly, leaving just 0.2 percent ties. In addition, we used a likelihood ratio test to reject the null hypothesis that all estimated coefficients were jointly zero; significance was less than 1 percent.

A number of factors were important to rural mothers' decision to work. We find that both "other income" and TANF payments have a statistically important effect on the probability of their working; the greater the levels of "other income" or TANF, the lower the probability of a rural mother working. However, the odds of working when a mother gains an additional dollar per week of "other income" or TANF are 99 percent of the odds of working without that extra dollar per week. While the estimated effects of "other income" and TANF on the probability of working are statistically significant, the magnitudes of these two effects appear to be very small. ${ }^{2}$ Each mother was asked whether she received the EITC for the previous year. If she reported receiving the tax credit, then either she or her spouse/partner worked in the prior year. Having received an EITC refund resulted in a 1.7 times higher probability of the mother's working.

A number of human capital and individual characteristics were found to be important to the probability of maternal employment. The odds of a high school graduate working were 57 percent greater than those for a mother who did not have a high school diploma. While the

\footnotetext{
${ }^{2}$ However, suppose a mother was to gain an additional $\$ 100$ in weekly TANF payments, her odds of working are then 0.54 . In other words, the odds of her working would be about $46 \%$ lower with the extra $\$ 100$ per week.
} 
estimate shows a substantial effect on the probability of working, this variable's effect is statistically important at only the 13 percent level of significance. For this group of rural women, having some additional college education does not statistically increase the probability of working. Other human capital factors that influenced mothers' probability of working included being licensed to drive and being at a high risk for depression. Having a driver's license increased a mother's odds of working by 2.4 times the odds of someone without a license. The effect was statistically significant at the 1 percent level or better. Rural mothers who were at risk of being clinically depressed were 34 percent less likely to work (0.66) than those who were not at risk of depression. This effect was statistically important at the 10 percent level of significance. While this result was not as statistically powerful, nonetheless, it was noteworthy. Although specific life skills have not been considered human capital variables by some researchers, we expected them to positively affect the probability of rural mothers working. However, the statistical evidence to support this prediction was relatively weak. Knowledge of job application procedures increased the probability of working. Although the odds of working were estimated to be more than six times greater for those mothers with job application knowledge compared to those without this knowledge, the effect is statistically weak (11 percent level of significance).

Age is an individual characteristic that is important to the probability of rural mothers being employed. Older mothers were more likely to work. Each additional year of age increased the odds of maternal employment by about 4.5 percent.

Household characteristics all affected individual work decisions. As mentioned previously, the most important household factor was the availability of child care assistance. The odds of a rural mother working were 173 percent greater for those with child care assistance than 
for those without. Household size also has a positive effect on the probability of working. Each additional member in the household results in a 26 percent increase in the odds of mothers working. When the mother's spouse or partner worked, she had a higher probability of working. The odds of working when the partner worked were 79 percent higher than the odds when the partner did not work. These three variables are all statistically significant at the 10 percent level or better.

\section{Number of Hours Supplied}

Table 3 shows the results of labor supply function estimation. The model explained about 33 percent of the variation in hours worked $\left(\mathrm{R}^{2}=0.334\right)$, and this proportion is statistically important at the 1 percent level of significant $(\mathrm{P}[\mathrm{F}>2.24]=0.004)$. However, unlike the results for estimation of the probability of working, few variables were statistically important in explaining the number of hours worked by these mothers. For our sample of rural mothers, we found that increased wages reduced hours worked at the 5 percent level. ${ }^{3}$ These results suggest that the negative income effect outweighed the positive substitution effect for the labor/leisure trade-off. We also found negative effects of other income sources. TANF payments negatively affected hours supplied, although this effect was not statistically significant. We found other sources of income, for example from a partner working, also had a negative effect on hours supplied, significant at about the 10 percent level. We found that receiving the EITC in the previous year had virtually no effect on hours supplied. Although it is clear that the EITC affected the probability of maternal employment, it did not affect the number of hours worked.

\footnotetext{
${ }^{3}$ If wage were to be jointly endogenous, or a random regressor correlated with the disturbances of the hours worked equation, then the parameter estimates could be inconsistent. A Hausman specification test was conducted. We conclude from the chi-square test statistic $\left(\chi_{20}^{2}=0.26\right)$ that an instrumental variable approach was not necessary.
} 
Individual and household characteristics had no statistically significant effects on the number of hours supplied by these rural mothers. Joint hypothesis tests for these groups of variables confirmed the lack of statistical significance seen across all variables in these two categories. We also found that the county unemployment rate, a measure of local job market characteristics, was not a significant predictor of the number of hours worked. However, important in the model were two job characteristics. Those individuals who received health insurance worked an additional 10 hours per week, while those who received overtime benefits worked an additional 5 hours per week, on average.

\section{Discussion}

The EITC has been lauded as a successful policy strategy to increase employment among low-income workers. We tested the effect of the EITC on the probability that the rural mothers in our sample would be employed. We found that the reported receipt of the EITC by the family in the previous year did increase maternal employment. This result supports the findings of other studies that have established the EITC to be a substantial incentive for mothers to work (Ellwood, 2000; Grogger, 2003; Hotz \& Scholz, 2003; Meyer \& Rosenbaum, 2001).

Another government benefit program found to increase labor force participation is child care assistance. The receipt of child care assistance increased the probability that a mother would be working. This result verifies the conclusions of many other studies that the cost of child care can be a significant barrier to maternal employment, and assistance with this will enable mothers

to enter the labor force (Connelly \& Kimmel, 2000; Martinson, 2000; McKernan et al., 2002). At the same time, there were other government policies that reduced mothers' probability of work. An example is the TANF program. We found that the income received per month through TANF reduced the probability of working by one percent for each dollar received. Amount of "other 
income" received also lowered the probability of mothers' employment. The source of this income was most likely a partner's earnings and, it is also conceivable, that it included food stamps. This finding is similar to that of Livermore and Powers (2006) that unwed mothers are less likely to be employed the year after childbirth if they received TANF or food stamps.

Although the literature suggests that human capital variables are strong predictors of employment for most workers, it may not be so for rural low-income mothers, since jobs available to them often do not require high levels of education (Bartik, 1997). Our study did not find the level of education to be significantly related to either employment status or hours worked. Since our education variable was categorical, we used high school graduation and some college as the variables of interest. High school graduation is required for many types of jobs, however, it is possible that a relationship might be more evident if education were a continuous variable.

As part of human capital, we also included four job-related life skills (ability to create a resume, apply for jobs, locate job training, and locate child care) as well as the ability to drive a vehicle, measured by the possession of a driver's license. While the other life skills were not related to rural low-income mothers' employment status, the odds of working for mothers possessing a driver's license were 140 percent greater than the odds of working for those without a license; this effect was highly significant. Having a car and being able to drive it are often vital to holding a job in most rural counties due to the lack of public transportation options.

Yet another component of human capital, in addition to educational levels and skills, is health (Kooreman \& Wunderink, 1997). We used mental health in the model, which is measured using the score on the CES-D (Center for Epidemiological Studies - Depression scale) scale that predicts risk for clinical depression. The odds of working for rural mothers who were at risk of 
depression were 34 percent lower. This effect was statistically important at the 10 percent level of significance, supporting the findings of Olson and Pavetti (1996) and Zaslow et al. (2001).

The literature revealed that individual characteristics such as age, ethnicity, marital status, household size and composition, as well as number and age of children were not strongly predictive of employment status. We found that only age was related to participation in paid work; in our sample, older mothers were more likely to work.

Local job conditions, including unemployment rate, have been shown to affect work participation among welfare leavers and other low-wage workers (Boushey, 2002, Urban \& Olson, 2005). However, that did not prove significant in our equation. Perhaps this is due to the fact that we were comparing rural counties and, as a result, it is possible that the variation in unemployment rate was not sufficiently large to influence the probability of working.

Although the OLS equation for hours worked was significant, few variables proved predictive. With higher wages, expectations are that mothers would be willing to supply more hours to the labor market. For the mothers in our study, however, wages paid reduced the hours worked, indicating that they valued leisure time or that, possibly, child care arrangements and costs limited the hours that mothers were able to work before it became disadvantageous for them to work. Partner's earnings reduced the mother's work time, as mothers and partners made joint decisions about how to maximize the use of their time. In a previous study, we found that partners were more likely to have higher mean wages than the mothers, so that decisions regarding allocation of time between the labor force and child care may have led to a reduction of mother's time in paid work and an increase in partner's time in paid work (Seiling, 2004). Having health insurance and being able to get overtime were both related to increased time in the workplace for mothers in our sample. This may be related to the requirement that they 
work full-time in order to get these benefits and a willingness to work longer hours to qualify for them. Since previous studies have reported on the importance of health insurance to low-income mothers, especially to rural mothers (Lee et al., 2004; Martinson, 2000; McKernan et al., 2002), it is reasonable that mothers would work full-time in order to qualify for this benefit.

\section{Conclusions and Policy Implications}

Policymakers consider employment to be the key to improving the economic fortunes of poor families. For many low-income mothers, however, employment results in a constant balancing act between meeting the obligations of work and coping with the responsibilities of motherhood. Working mothers in rural areas may confront additional challenges such as inaccessible and unaffordable child care services, unreliable transportation, and inadequate job opportunities. All these disadvantages create greater obstacles for rural low-income mothers' participation in the labor market.

In this paper, we examined the effects of a variety of personal, household, and job variables on rural low-income mothers' decision to work as well as the number of hours they are willing to supply the labor force. The 412 rural mothers in this study came from 13 states that represent the four geographic regions, Northeast, South, Midwest, and West. The sample was not randomly selected; nevertheless, the results of the analysis provide important insights into the decision-making behavior of rural mothers regarding employment.

The logistic regression model used in this analysis correctly predicted 80 percent of rural maternal employment. Rural mothers who worked tended to be older, better educated, and less likely to suffer from depression. The EITC appears to provide an incentive for employment; those rural mothers who received the tax credit in the previous year were more likely to work. At the same time, the mothers who are employed were less likely to receive income from TANF or 
from another source. Rural mothers who were more likely to participate in the labor force also included those who are licensed to drive, have a working spouse or partner, have child care assistance, and live in larger households.

Once rural mothers decide to engage in paid employment, they are faced with a second question, that is, how many hours do they supply the labor market? Our model explained about 33 percent of the variation in hours supplied by rural low-income mothers. Those who received higher wages and those who relied on income from a working spouse or partner tended to supply fewer hours to the labor force. Another noteworthy observation is that while those who received the EITC were more likely to work, the tax credit did not seem to affect the number of hours they worked.

Interestingly, none of the individual and household characteristics had any statistically significant effects on how many hours rural mothers would spend in the labor force. The results, however, highlighted the importance of two job characteristics: health insurance and overtime benefits. Those rural mothers who received health insurance and overtime benefits were likely to spend more hours in the labor force. Local job market conditions may come into play when employers limit the number of hours available in some jobs or to some workers, constraining employees' work hours.

The results of this study have relevance to public policy at various levels. Firstly, the data were collected after the passage of welfare reform legislation. By looking at both the decision to work as well as the hours supplied to the labor force, we provide a more comprehensive picture of poor, rural mothers' labor force participation, the cornerstone of welfare reform. Secondly, since rural areas are susceptible to higher and more persistent poverty, an understanding of rural 
low-income mothers' economic behavior can help rural community leaders to create effective development priorities and strategies.

Two salient points worth noting are that economic security requires most rural lowincome mothers to be employed, and important benefits, such as health insurance, are usually a result of full-time employment. It is evident from our analyses that in order for these mothers to enter the labor market with greater ease, employment and other support services must be available and accessible. Services that are important to their decision to work include mental health counseling, education, job training, child care, transportation, and general support services such as help in obtaining a driver's license. Low wages mean some mothers must have subsidized services to make their work pay. Child care assistance, publicly supported transportation options, and Medicaid coverage of mental health services are important policy initiatives that can enable rural mothers to become committed to paid work. Without such services to facilitate their entry into the labor force, some rural low-income mothers would find it impossible to be employed while others would continue to face hardships as they juggle the demands of work with familial responsibilities. 
Table 1

Socio-Demographic Characteristics of Rural Mothers $(N=412)$

\begin{tabular}{ccc}
\hline Characteristic & Working & Non-Working \\
& $\mathrm{N}=208$ & $\mathrm{~N}=204$ \\
& $\%$ & $\%$
\end{tabular}

Age

Under 25

28.8

68.1

34.3

$25-45$

3.1

Over 46

28.0

63.7

2.0

Median age

27.0

Ethnicity

White, non-Hispanic

64.4

22.6

Hispanic

8.7

63.2

African American

4.3

20.1

Other

8.8

7.9

Marital Status

Single

28.4

53.4

21.1

Married/living with partner

13.3

65.6

Divorced/separated

18.3

Partner's Working Status

Working

48.6

49.3

Non-Working

51.4

50.7

Education

More than high school

46.5

30.9

34.0

High school

22.6

25.6

Less than high school

40.4

Number of Children

One

32.2

32.4

Two

28.4

31.4

Three or more

39.4

36.2

Mean age of youngest child in years

3.6

2.9

Monthly Income

$<\$ 1,000$

32.8

25.0

54.4

$\$ 1,000-\$ 1,499$

19.0

19.5

$\$ 1,500$ - $\$ 1,999$

15.9

17.0

$\$ 2,000-\$ 2,500$

7.3

7.5

$>\$ 2,500$

$\$ 1,381.52$

1.6

Median monthly income

$\$ 1,188.88$ 
Table 2

Estimated Logistic Regression Results for the Probability of Working $(N=412)$

\begin{tabular}{|c|c|c|c|c|c|}
\hline Variable & Estimate & Std. Error & $\chi^{2}$ & $\mathrm{P}\left(\chi^{2}\right)$ & Odds Ratio \\
\hline Intercept & -2.8965 & 1.6254 & 3.176 & 0.075 & \\
\hline \multicolumn{6}{|l|}{ Individual Characteristics } \\
\hline Age & 0.0390 & 0.0200 & 3.792 & 0.052 & 1.040 \\
\hline Hispanic & -0.1986 & 0.4315 & 0.212 & 0.645 & 0.820 \\
\hline African American & -0.0556 & 0.4860 & 0.013 & 0.909 & 0.946 \\
\hline Other ethnic group & -0.9548 & 0.7288 & 1.717 & 0.190 & 0.385 \\
\hline \multicolumn{6}{|l|}{ Household Characteristics } \\
\hline Household size & 0.2330 & 0.1249 & 3.480 & 0.062 & 1.262 \\
\hline Age of youngest child & -0.6333 & 0.4579 & 1.913 & 0.167 & 0.531 \\
\hline Child care assistance & 1.0050 & 0.3418 & 8.645 & 0.003 & 2.732 \\
\hline Lives with partner & -0.1323 & 0.3569 & 0.137 & 0.711 & 0.876 \\
\hline Partner works & 0.5823 & 0.3539 & 2.708 & 0.100 & 1.790 \\
\hline Suffers abuse & 0.3434 & 0.3871 & 0.787 & 0.375 & 1.410 \\
\hline \multicolumn{6}{|l|}{ Human Capital Variables } \\
\hline At least HS degree & 0.4536 & 0.2994 & 2.294 & 0.130 & 1.574 \\
\hline Some college & 0.0130 & 0.3467 & 0.001 & 0.970 & 1.013 \\
\hline Depression score $>16$ & -0.4164 & 0.2575 & 2.615 & 0.106 & 0.659 \\
\hline Licensed to drive & 0.8752 & 0.3325 & 6.929 & 0.009 & 2.399 \\
\hline Able to create a resume & 0.3560 & 0.3175 & 1.257 & 0.262 & 1.428 \\
\hline Able to locate job training & -0.1520 & 0.3128 & 0.236 & 0.627 & 0.859 \\
\hline Able to locate child care & 0.2351 & 0.3429 & 0.470 & 0.493 & 1.265 \\
\hline Able to apply for jobs & 1.8472 & 1.1589 & 2.541 & 0.111 & 6.342 \\
\hline \multicolumn{6}{|l|}{ Household Income Sources } \\
\hline TANF payments & -0.0062 & 0.0011 & 29.609 & $<.0001$ & 0.994 \\
\hline Earned Income Tax Credit & 0.5343 & 0.2695 & 3.929 & 0.048 & 1.706 \\
\hline Other income & -0.0010 & 0.0002 & 21.276 & $<.0001$ & 0.999 \\
\hline \multicolumn{6}{|l|}{ Local Economic Conditions } \\
\hline County unemployment & 0.0045 & 0.1699 & 0.001 & 0.979 & 1.005 \\
\hline Psuedo R2 & 0.2225 & & & & \\
\hline Likelihood Ratio $\left(\chi^{2}\right)$ & 112.21 & & & & \\
\hline
\end{tabular}


Table 3

Estimated Results for Labor Supply - Ordinary Least Squares Estimates $(N=208)$

\begin{tabular}{|c|c|c|c|}
\hline Variable & Estimate & Std. Error & $\mathrm{t}$ \\
\hline Intercept & $33.19991 *$ & 9.602 & 3.46 \\
\hline \multicolumn{4}{|l|}{ Individual Characteristics } \\
\hline Age & 0.2888 & 0.418 & 0.69 \\
\hline Hispanic & 0.1128 & 3.521 & 0.03 \\
\hline African American & 1.0509 & 4.098 & 0.26 \\
\hline Other ethnic group & -6.3990 & 6.731 & -0.95 \\
\hline \multicolumn{4}{|l|}{ Household Characteristics } \\
\hline Household size & 0.1784 & 1.021 & 0.17 \\
\hline Age of youngest child & 0.2526 & 3.415 & 0.07 \\
\hline Child care assistance & 1.2300 & 2.379 & 0.52 \\
\hline Lives with partner & 3.7746 & 3.084 & 1.22 \\
\hline Partner works & 3.1126 & 3.574 & 0.87 \\
\hline Suffers abuse & -0.4231 & 2.861 & -0.15 \\
\hline \multicolumn{4}{|l|}{ Human Capital Variables } \\
\hline At least HS degree & 0.9509 & 2.442 & 0.39 \\
\hline Some college & 0.9206 & 2.752 & 0.33 \\
\hline Experience (years of potential experience) & 0.0008 & 0.366 & 0.00 \\
\hline Depression score $>16$ & -1.9466 & 2.101 & -0.93 \\
\hline Licensed to drive & 0.0171 & 3.014 & 0.01 \\
\hline \multicolumn{4}{|l|}{ Household Income Sources } \\
\hline Wage & $-1.1739 *$ & 0.480 & -2.45 \\
\hline TANF payments & -0.0059 & 0.011 & -0.56 \\
\hline Earned Income Tax Credit & 0.0754 & 2.347 & 0.03 \\
\hline Other income & -0.0044 & 0.003 & -1.62 \\
\hline \multicolumn{4}{|l|}{ Job Characteristics } \\
\hline Health insurance & $10.0053^{*}$ & 2.479 & 4.04 \\
\hline Overtime & $4.9802 *$ & 2.311 & 2.16 \\
\hline \multicolumn{4}{|l|}{ Local Economic Conditions } \\
\hline County unemployment & -1.3517 & 1.420 & -0.95 \\
\hline $\mathrm{R}^{2}$ & 0.3324 & & \\
\hline F-statistic & $2.24 *$ & & \\
\hline
\end{tabular}

$* \mathrm{p}<0.01$ 


\section{References}

Acs, G., \& Loprest, P. (1999). The effect of disabilities on exits from AFDC. Journal of Policy Analysis and Management, 18, 28-49.

Bartik, T. J. (1997). Jobs for welfare recipients. Employment Research. Retrieved August 5, 2006, from http://www.upjohninst.org/publications/newsletter/tjb597.pdf

Bassuk, E.L, Weinreb, L.F., Buckner, J.C., Browne A., Salomon, A., \& Bassuk, S.S. (1996). The characteristics and needs of sheltered homeless and low-income housed mothers. Journal of the American Medical Association, 276, 640-646.

Beggs, J.J., Haines, V. A. \& Hulbert, J. S. (1996). Revisiting the rural-urban contrast: Personal networks in nonmetropolitan and metropolitan settings. Rural Sociology 61, 306-25.

Berg, L., Olson, L., \& Conrad, A. (1992). Causes and implications of rapid job loss among participants in welfare-to-work programs (Working Paper 92-1). Evanston, IL: Northwestern University, Center for Urban Affairs and Policy Research.

Blau, F.D., Ferber, M.A., \& Winkler, A.E. (2002). The Economics of Women, Men, and Work ( $4^{\text {th }}$ ed.). Upper Saddle River, New Jersey: Prentice Hall.

Bloom, D., \& Michalopoulos, C. (2001). How welfare and work policies affect employment and income: A synthesis of research. Manpower Demonstration Research Corporation.

Blundell, R. W. and T. MaCurdy (1999). Labor supply: A review of alternative approaches. In O. Ashenfelter \& D. Card (ed.), Handbook of labor economics, Vol. 4 (4th ed., pp 1559-1695).

Elsevier.

Boushey, H. (2002). Staying employed after welfare: Work supports and job quality vital to employment tenure and wage growth (EPI Briefing Paper 128). Retrieved August 5, 2006, from http://www.epinet.org/content.cfm/briefingpapers_bp128

Boushey, H., \& Rosnick, D. (2004). For welfare reform to work, jobs must be available. Retrieved August 5, 2006, from

http://www.cepr.net/documents/publications/welfare_reform_2004_04.pdf

Brandon, P.D., \& Hogan, D.P. (2001). The effects of children with disabilities on mothers' exit from welfare (JCPR Working Paper 300.) Chicago: Joint Center for Poverty Research, Northwestern University/University of Chicago. Retrieved August 5, 2006, from http://www.jcpr.org/wpfiles/brandon_hogan_SRI2001.pdf

Brewster, K. L., \& Padovic, I. (2002). No more kin care? Change in black mothers' reliance on relatives for child care, 1977-94. Gender \& Society, 16, 546-563. 
Colton, C., Bania, N., Martin, T., \& Lalich, N. (2003, June). How are they managing? A retrospective of cuyahoga county families leaving welfare. Cleveland, $\mathrm{OH}$ : Case Western Reserve University, Mandel School of Applied Social Sciences, Center on Urban Poverty and Social Change. Retrieved August 5, 2006, from http://hdl.handle.net/2186/ksl:2006052576/ Lickfelt-HATMoct-2004.pdf

Colten, M.E., Consenza, C. \& Allard, M.A., (1996). Domestic violence among Massachusetts AFDC recipients: Preliminary results. Boston: University of Massachusetts, Center for Survey Research.

Curcio, C. 1997. The Passaic County study of AFDC recipients in a welfare-to-work program. Passaic County, N.J.: Passaic County Board of Social Services.

Committee on Ways and Means. (2000). 2000 Green Book (1 $17^{\text {th }}$ ed.). Washington, D.C.: U.S. House of Representatives.

Connolly, R., \& Kimmel, J. (2000). Marital status and full-time/part-time work status in child care choices. Retrieved August 19, 2006, from http://www.upjohninst.org/publications/wp/ 99-58.pdf

Danziger, S. (2002). Approaching the limit: Early national lessons from welfare reform. In B.A. Weber, G.J. Duncan \& L.A. Whitener (Eds.), Rural dimensions (pp. 25-49). Kalamazoo, MI: W.E.Upjohn Institute for Employment Research.

Duncan, G., Whitener, L.A., \& Weber, B.A. (2002). "Lessons learned: Welfare reform and food assistance in rural America." In B.A. Weber, G.J. Duncan \& L.A. Whitener (Eds.), Rural dimensions (pp. 455-470). Kalamazoo, MI: W.E.Upjohn Institute for Employment Research.

Edin, K. \& Lein, L. (1997). Making ends meet: How single mothers survive welfare and lowwage work. New York: Russell Sage Foundation.

Ellwood, D. T. (2000). The impact of the earned income tax credit and social policy reforms on work, marriage and living arrangements (JCPR Working Papers 124). Northwestern University/University of Chicago Joint Center for Poverty Research. Retrieved August 5, 2006, from http://www.jcpr.org/wp/wpdownload.cfm?pdflink=wpfiles/ellwood_eitc99_update.PDF

Feindis, J. L., \& Jensen, L. (1998). Employment opportunities in rural areas: Implications for poverty in a changing policy environment. American Journal of Agricultural Economics, 80, 1000-1007.

Fremstad, S. (2004, January 30). Recent welfare reform research findings: Implications for TANF reauthorization and state TANF policies. Retrieved August 18, 2006, from http://www.cbpp.org/1-30-04wel.htm 
Grogger, J. (2003). The effects of time limits, the EITC, and other policy changes on welfare use, work, and income among female-headed families. The Review of Economics and Statistics, 85, 394-408.

Hao, L. (1996). Family structure, private transfers, and the economic well-being of families with children. Social Forces, 75, 269-292.

Harvey, E. (1999). Short term and long term effects of early parental employment on children of the National longitudinal Survey of Youth. Development Psychology, 35 (2), 445-59.

Henry, M., \& Drabenstott. M. (1996). A new micro view of the U.S. rural economy. Economic Review, 2nd Quarter, 53-70.

Hotz, J., \& Scholz. J. (2003). The Earned Income Tax Credit. In R. A. Moffitt (Ed.), Meanstested transfer programs in the United States. University of Chicago Press.

Hunts, H. J. H., \& Avery, R. J. (1998). Relatives as child care givers: After hours support for nontraditional workers. Journal of Family and Economic Issues, 19, 315-341.

Kooreman, P., \& Wunderink, S. (1997). The economics of household behavior. New York: St. Martin's Press.

Lee, S., Oh, G-T., Hartmann, H., \& Gault, B. (2004). The Impact of disabilities on mothers' work participation: Examining differences between single and married mothers. Retrieved August 18, 2006, from http://www.iwpr.org/pdf/DisabilityMothersWork.pdf

Lloyd, S. (1996). The effects of violence on women's employment. Chicago: Northwestern University, Institute for Policy Research.

Leon, A.C., \& Weissman, M.M. (1993). Analysis of NIMH's existing epidemiologic catchment area (ECA) data on depression and other affective disorders in welfare and disabled populations. New York: Columbia University College of Physicians and Surgeons.

Lin, N. \& Dumin, M. 1986. Access to occupations through social ties. Social Networks 8, 365385.

Livermore, W., Powers, R. (2006). Employment of unwed mothers: The role of government and social support. Journal of Family and Economic Issues, 27, 479-494.

Looney, A. (2005). The effect of welfare reform and related policies on single mothers' welfare use and employment in the 1990s. Finance and Economics Discussion Series. U.S. Federal Reserve, Division of Research and Statistics and Monetary Affairs. Retrieved August 27, 2006, from http://www.federalreserve.gov/Pubs/feds/2005/200545/200545pap.pdf

Loprest, P. (2003, August). Fewer welfare leavers employed in weak economy. Retrieved August 5, 2006, from http://www.urban.org/url.cfm?ID=310837 
Martinson, K. (2000). The national evaluation of welfare-to-work strategies: The experiences of welfare recipients who find jobs. Retrieved August 5, 2006, from www.mdrc.org/Reports2001/NEWWS_PE_Experiences/NEWWS-PE-Experiences.pdf

McKernan, S-M., Lerman, R., Pindus, N., \& Valente, J. (2002). The impact of welfare policy on the employment of single mothers living in rural and urban areas. In B.A.Weber, G.J. Duncan, \& L.A. Whitener, (Eds.), Rural dimensions (pp. 257-286). Kalamazoo, MI: W.E.Upjohn Institute for Employment Research.

Meyer, B.D., \& Rosenbaum, D.T. (2001). Welfare, the Earned Income Tax Credit, and the labor supply of single mothers on welfare. Quarterly Journal of Economics, 116, 1063-1114.

Miller R. J. \& Darlington, Y. (2002). Who supports? The providers of social support to dualparent families caring for young children. Journal of Community Psychology 30, 461-73.

Moffitt, R. A. (2002). From welfare to work: What the evidence shows. Retrieved August 27, 2006, from http://www.brookings.edu/ /media/Files/rc/papers/2002/01welfare_moffitt/pb13.pdf

Moore, K.A., Zaslow, M., Coiro, M.J., Miller, S.M., \& Magenheim, E.B. (1995). How well are they faring? AFDC families with preschool-aged children in Atlanta at the outset of the JOBS evaluation. Washington D.C.: U.S. Department of Health and Human Services.

Mroz, T. A. (1987). The sensitivity of an empirical model for married women's hours of work to economic and statistical assumptions. Econometrica, 55, 765-99.

Nelson, M. K. \& Smith, J. (1999). Working hard and making do: Surviving in small town America. Berkeley: University of California Press.

NICHD Early Child Care Research Network (1997). Familial factors associated with the characteristics of nonmaternal care for infants. Journal of Marriage and the Family, 59, 389-408.

Olson, K., \& Pavetti, L. (1996). Personal and family challenges to the successful transition from welfare to work. Washington D.C.: The Urban Institute.

O’Neill, J.E., \& Hill, A.M. (2001). Gaining ground? Measuring the impact of welfare reform on welfare and work (Civic Report 17). Retrieved August 5, 2006, from http://www.manhattan-institute.org/pdf/Cr_17.pdf

Perry-Jenkins, M., Repetti, R.L., and Crouter, A.C. (2000). Work and family in the 1990s. Journal of Marriage and the Family, 62, 981-98.

Polit, D. F., Widom, R., Edin, K., Bowie, S., London, A.S., Scott, E.K., \& Valenzuela, A. (2001). Is Work enough? The experiences of current and former welfare Mothers who work. Retrieved August 28, 2006, from http://www.mdrc.org/publications/74/full.pdf 
Quint, J., \& Musick,. J. (1994). Lives of promise, lives of pain: Young mothers after New Chance. New York: Man power Demonstration Research Project.

Quint, J., Polit, D., Bos, H., \& Cave, G. (1994). New Chance: Interim findings on a comprehensive program for disadvantaged young mothers and their children. New York: Manpower Demonstration Research Corporation.

Ribar, D. (2000). Transitions from welfare and the employment prospects of low-skill workers. Southern Economic Journal, 71, 514-533.

Ross Phillips, K. (2002). Parent work and child well-being in low-income families. Retrieved August 30, 2006, from http://www.urban.org/uploadedPDF/310509_OP56.pdf

Schultz, T. W. (1961). Investment in human capital. American Economics Review, 51, 1-17.

Seiling, S. (2004). Family sustainability: Views from Ohio rural low-income mothers and county leaders. Paper presented at Cultures, Governance and Rural Poverty in the Midwest: Toward a Regional Research Framework to Reduce Poverty. Chicago, IL.

Shank, S. E. (1988). Women and the labor market: The link grows stronger. Monthly Labor Review, 111(1), 3-8.

Sherman, A., Fremstad, S., \& Parrott, S. (2004). Employment rates for single mothers fell substantially during recent period of labor market weakness. Retrieved September 10, 2006, from http://www.cbpp.org/6-22-04ui.pdf

United States Bureau of the Census. (n.d.). Historical Poverty Tables (Table 4). Retrieved April 30, 2007, from http://www.census.gov/hhes/www/poverty/histpov/hstpov4.html

United States Department of Labor. (2007). Quick Stats 2006. Retrieved April 30, 2007, from http://www.dol.gov/wb/stats/main.htm

Urban, J., \& Olson, P. (2005). A comprehensive employment model for low-income mothers. Journal of Family and Economic Issues, 26, 101-122.

Wan, C. K., Jaccard, J., \& Ramey, S. L. (1996). The relationship between social support and life satisfaction as a function of family structure. Journal of Marriage and the Family, 58, 502-513.

Warr, P. (1999). Well-being and the workplace. In D. Kahneman, E. Diener, \& N, Schwarz (Eds.), Well-being: The foundations of hedonic psychology (pp. 392-412). New York: Russell Sage Foundation.

Weber, B., \& Jensen, L. (2004). Poverty and place: A critical review of the rural poverty literature. Retrieved on September 10, 2006, from http://www.rprconline.org/WorkingPapers/ WP0403.pdf 
Wellman, B. \& Wortley, S. (1990). Different strokes for different folks: Community ties and social support. American Journal of Sociology 96, 558-88.

Wheelock, J., Oughton, E., \& Baines, S. (2003). Getting by with a little help from your family: Toward a policy-relevant model of the household. Feminist Economics, 9(1), 19-45.

Zaslow, M.J., \& Emig, C. A. (1997). When Low-Income Mothers Go to Work: Implications for Children. The Future of Children, 7(1), 110-115.

Zaslow, M.J., Hair, E., M. Dion, R., Ahluwalia, S.K., \& Sargent, J., (2001). Maternal depressive symptoms and low literacy as potential barriers to employment in a sample of families receiving welfare: Are there two-generational implications? Women and Health, 32(3), 211-251.

\section{Acknowledgments}

This research was supported in part by USDA/CSREES/NRICGP Grant Number 200135401-10215 \& 2002-35401-11591, 2004-35401-14938. Data were collected in conjunction with the cooperative multi-state research project, NC-223/NC-1011, "Rural Low-Income Families: Monitoring Their Well-being and Functioning in the Context of Welfare Reform.” Cooperating states are California, Indiana, Kentucky, Louisiana, Massachusetts, Maryland, Michigan, Minnesota, Nebraska, New Hampshire, New York, Ohio, and Oregon.

The authors gratefully acknowledge the assistance of Megan Dolan, graduate research assistant, Peter St. Marie and Thomas Martin, undergraduate research assistants, all at the University of Massachusetts Amherst. 